\title{
PERCEIVED IMPEDIMENTS TO EXPORT INVOLVEMENT AMONG SMALL AND MEDIUM SIZED FIRMS: NON-EXPORTERS PERSPECTIVE
}

\section{Mercy Mpinganjira: University of Johannesburg}

\section{SYNOPSIS}

Purpose: The main purpose of this paper is to examine perceived impediments to export involvement among non-exporting small and medium sized firms (SME's) in Malawi. The study also examines levels of interest in exporting among the firms.

Problem investigated: Many countries have programs aimed at promoting export involvement among SME's. Despite this, most SME's continue to ignore exporting as a viable business strategy. Information on perceived impediments to export involvement especially from the non-exporters' perspective is often lacking hence the need for this study.

Methodology: Data was collected from 80 owner managers of non-exporting SME's. A structured questionnaire was the main instrument used to collect data. Personal interviews were also held with managers for the purposes of probing their answers to the questions in the questionnaire. Statistical Package for Social Science (SPSS) version 18 was used to analyse the quantitative data obtained from use of the structured questionnaire. Qualitative data obtained through personal interviews was analysed used thematic analysis.

Findings: The findings of the study showed significant levels of interest in exporting among the firms. The majority of the owner managers indicated willingness to exploit export opportunities that may be readily available to them. The findings however showed that just over half of the respondents had discussed or investigated the possibility of exporting before. On impediments to exporting, the findings showed that managers perceive many factors as important impediments to their firm's involvement in exporting. The top two most important impediments were internal to the firm and related to human resource issues. They included insufficient knowledge about export opportunities and lack of personnel knowledgeable in exporting.

Originality and value of the research: A review of literature shows that most export promotion studies tend to focus more on issues relating to firms already involved in exporting. Efforts aimed at encouraging more SME's to take up exporting are however likely to fail if they do not address non-exporters' concerns.

Conclusion: There are many non-exporting firms which would consider exporting if only they could receive appropriate help. It is thus important for officials involved in export promotion to understand perceived impediments to export involvement from the non-exporters perspective. Such information can help in designing export promotional programs that will address concerns and help improve uptake of exporting as a business strategy. This study contributes towards this understanding.

Key words: Export involvement, impediments, non-exporters, small and medium sized firms (SME's), Malawi.

\section{INTRODUCTION}

World trade, measured as the total value of export of goods and services, has grown significantly over the past three decades, climbing from approximately 1.9 trillion US dollars in 1980 to 6.4 trillion US dollars in the year 2000 and slightly over 12.3 trillion US dollars in the year 2009 (World Trade Organisation 2010:12-16; International Monetary Fund 1986:25-30). Exporting has actually been one of the fastest growing economic activities, exceeding the average rate of growth in world output over the last three decades. Increased trade liberalisation and economic integration measures undertaken by many countries during the period coupled by growing domestic economies, advances in transportation, 

small and medium sized firms: non-exporters perspective

information and telecommunication technology are the main factors that have contributed to the increased engagement of firms in export activities over the years (Lee and Carter, 2009:9; Pinho and Martins, 2010:255).

Although world trade and exports in particular have grown significantly over the decades, the performance of African countries, especially those in sub-Saharan Africa has not been impressive. According to World Trade Organisation (2010:10) as well as International Monetary Fund (1986:25-30) African countries contributed about 3.2 percent of total world exports in 2009 compared to 4 percent in 1980. Thus Africa's share of world exports is not only significantly small, but also statistics show that the continents share has actually declined over the decades. Despite this (Miankel et al 2009:1) observed that there is a growing recognition among developing countries that besides foreign direct investment, exporting remains one of the most important channels through which they can link themselves with the world economy to their own great benefit. Lages and Montgomery (2005:756) as well as Yannopoulos $(2010: 82)$ noted that from the point of view of most national governments, increasing export activity is extremely attractive because it enables them accumulate foreign exchange reserves; helps national industries to develop, improve productivity and create new jobs; and can result in increased government revenue from taxes. Increased export activity has thus the potential to enhance society's well being.

In light of the benefits associated with exporting, many countries around the world have in place measures aimed at encouraging more of their firms to take up exporting and enabling existing exporters enhance their performance in the targeted international markets. Some of the measures undertaken by the government of Malawi to help stimulate the exports include the creation of various export incentives including allowing exporters to retain some of the foreign exchange obtained through export sales; reduced custom duties on imports of some capital equipment used mainly in the manufacture of exports and an export tax allowance on export revenues from non-traditional exports (i.e. exports other than tobacco, coffee, sugar and tea). The government also established the Malawi Export Promotion Council (MEPC), a parastatal organisation whose main objectives include working with the business community providing them with export related information and assisting them in acquiring export related skills. It also helps ensure that export related concerns of the business community are given appropriate attention by government. The government has established several export processing zones in the country that give extra incentives to business if they exclusively manufacture for export markets. It has also entered into several bilateral and multilateral trade agreements aimed at securing preferential access to markets of the country's exports. For example Malawi's exports enjoy preferential access to the European Union under the Everything But Arms (EBA) initiatives and also to Southern Africa Development Community (SADC) countries under the SADC trade agreement.

\section{LITERATURE REVIEW}

Exporting is by far the most common method used by businesses, both small and large, to enter international markets (Lee and Carter, 2009:232). For most small and medium sized firms, exporting is the only viable method through which they can enter international markets. This is because exporting, unlike other entry modes involves minimum risks and requires low financial and human resources (Pinho and Martins, 2010:255).

Ahmed et al (2006:661) observed that in general, the expansion of a nation's exports has positive effects on the growth of the economy as a whole. This is why in many countries around the world millions of dollars are currently being spent and countless programmes developed by governments for the purposes of stimulating their businesses including small and medium sized firms to take up exporting. Individual firms are however more likely to take up exporting not because of its potential impact on national 

small and medium sized firms: non-exporters perspective

development per se but rather because of its potential contribution to their business goals. Yannopoulos (2010:84-85) as well as Leonidou et al (2007:739) observed that the common benefits associated with export involvement include increased sales and profits, improved capacity utilisation, achievement of economies of scale and reducing risk associated with dependence on a single market. Exporting can also help enhance a firm's managerial skills and capabilities, better facilitate the use of resources as well as allow a firm to benefit from international competition thereby becoming a stronger player in its home market (Pinho and Martins, 2010:255). Singh et al (2010161:) as well as Ahmed et al (2006:664-665) observed that the benefits associated with exporting play a very important role in motivating individual firms to take up exporting. Leonidou (2004:280) however noted that that in order to effectively motivate local firms, particularly SME's, to enter foreign markets, it is necessary to understand not only the factors that stimulate them to export but also the impediments they face to in order successfully enter and operate in foreign markets.

A review of literature shows that factors both external and internal to the firm can act as impediments to export involvement. External impediments stem from the business environment both in the domestic and international markets. The Donor Committee for Enterprise Development (2008:2) noted that domestic environmental factors are of more concern in developing economies because their business environments are often not conducive to the achievement of international competitiveness. They defined the business environment as a complex of policy, legal, institutional, and regulatory conditions that govern business activities. They further noted that areas of concern in most developing countries are to do with problems relating to political stability and rule of law; skills and human resource development; economic predictability; equitable and efficient labour markets, open financial markets as well as infrastructure. Pinho and Martins (2010:257) noted that home market conditions characterised by lack of financial assistance/government incentives; qualified export related personnel including consultant expertise services; information technology platforms; as well as good communication infrastructures such as motorways and airports, make it difficult for domestic firms to successfully engage in export business.

According to Kalafsky (2009:48) as well as Su and Adams (2007:56) external impediments to export involvement associated with international markets are mainly due to the fact that moving products across international borders entails different business environments with different rules and regulations, business practices as well as customer attitudes. Altintas et al., (2007:39-43) and Singh et al., (2010:171) noted that conditions in international market environment including high levels of competition, high tariff rates, foreign rules and regulations, different customer habits as well as language differences can all act as significant barriers to export involvement. It is because of these differences that most often small and medium sized firms start their export business by targeting countries that are closer and culturally similar to their home countries (Hutchinson et al 2009:546).

While the importance of external factors in influencing firm export involvement cannot be disputed, on their own external factors are not adequate in explaining why some firms get involved in exporting while others do not despite facing similar domestic and foreign market conditions. Pinho and Martins (2010:257); Khorana et al., (2010:3); as well as Morgan (1999:329) argued that it is the managers' perceptions of environmental factors and the appropriateness of strategies to exploit these, which are more likely to be the major determinant of firms' export involvement and/or performance. Factors internal to the firm can thus offer a better explanation as to why within the same market some firms decide to get involved in exporting while others do not. Hutchinson et al (2009:548) observed that as far as internal barriers to internationalisation are concerned, two main theoretical perspectives on firm resources have been proposed in the broader business literature namely resource based view (RBV) and dynamic capabilities. They noted that at the centre of RBV are human, physical and organisational assets that can be used to implement value creating strategies. With regards to dynamic capabilities, they indicated that 

small and medium sized firms: non-exporters perspective

these are the antecedent organisational and strategic routines by which managers alter their resource base to achieve congruence with the changing environment.

Altintas et al (2007:47) noted that the common resource barriers to export involvement relate to finance, management time, production capacity and personnel with export skills. According to the OECD (2008:1) finance related issues, including lack of working capital to finance exports, difficulties accessing credit, cash flow and delays in payment, are often identified by businesses as the most significant barriers to export involvement. Shamsuddoha et al (2009:410) as well as Ruzzier et al (2007:26) however observed that lack of skilled human resources, in particular managers with knowledge of markets, consumer preferences and foreign market environment, is a critical internal barrier to export involvement. Knowledge in these areas helps to create sustainable competitive advantage for firms and enhance managerial capabilities to mobilise other resources for their international activities.

Although all firms face barriers to export involvement, most researchers note that important barriers will tend to differ depending on firm size, industry and stage in the internationalisation process. In general researchers argue that the barriers to entry that limit international expansion are systematically higher for smaller firms than for larger firms (Hutchinson et al 2009:545). This is mainly because smaller firms unlike larger businesses tend to have limited resources and internationalisation requires more resources. Additionally internationalisation by its nature involves a high degree of risk and smaller firms unlike larger ones have limited capacity to cope with the downside of foreign expansion. Neupert et al., (2006:537) noted that firms from different industries may perceive possible barriers to export involvement differently.

The stages theory to internationalisation suggests that firms get involved in export activities incrementally as they devote more resources as well as gain information and experience which helps them to expand their international business activities. In their review of the various studies on export development stages, Leonidou and Katsikeas (1996:518) noted that the export development process can be meaningfully viewed as consisting of three broad phases. These phases are the pre-engagement phase, where firms are not exporting; the initial phase, where firms are marginally involved in exporting; and the advanced phased, where firms are regular exporters and consider more committed forms of international business. In terms of barriers to export involvement, Pinho and Martins (2010:257) as well as Hook and Czinkota (1988:53) found that exporters tend to place more emphasis on operational issues such as controlling the physical flow of products in the target market and too much red tape. Non-exporters on the other hand were found to be more concerned with problems associated with initiation of export activity such as difficulties in raising initial capital and lack of information about exporting. It is also important to note that exporters or non-exporters are not a homogenous group. Within non-exporters one is likely to find some firms that are not interested with exporting while others may be interested. Some of the exporters may be regular exporters while others may be irregular exporters. Impediments to export involvement of major concern to the different groups may also be different.

\section{RESEARCH PROBLEM AND OBJECTIVES}

Ahmed et al., (2006:661) observed that countries can be able to increase their exports either by encouraging exporting firms to export more or by inducing non-exporters to begin exporting. According to Organisation for Economic Cooperation and Development (OECD) (2000:1) there is need for countries to pay particular attention to small and medium sized businesses in their export promotion efforts as these constitute a large number of businesses in most countries. In Malawi it is estimated that small and medium sized businesses constitute over 90 percent of all formal businesses in the country. The government of Malawi defines small businesses as those having between 5 and 20 full time employees and an annual turnover of above 1 million Malawi Kwacha (MK) up to 10 million. Medium sized 

small and medium sized firms: non-exporters perspective

businesses are firms employing between 21 and 100 employees and having an annual turnover of above 10 million up to 50 million MK (Malawi Government, 2007:4). In cases where an enterprise falls under different employment and annual turnover categories, the later is used to determine firm size.

Despite their large numbers and the many efforts undertaken by the government aimed at promoting export involvement, many small and medium sized businesses in Malawi continue to ignore exporting as a viable business strategy. Given the great importance of exports to the economy, there is need for increased efforts aimed at stimulating more businesses to take up exporting. The development of effective export promotion programs can however not take place without a better understanding of the factors that impede firms to take up exporting. This paper aims at contributing to this understanding by investigating perceived impediments to export involvement among non-exporting small and medium sized firms in Malawi. The specific objectives of the study include to (a) examine levels of interest in exporting among non-exporting small and medium sized firms (b) identify the important impediments to export involvement perceived by non-exporting firms (c) examine if there are significant differences in levels of perceived impediments to export involvement between non-exporters that had discussed or investigated the possibility of exporting before and those that had not as well as between firms in different industries (d) discuss the implications of the findings on the development of export promotion programs.

\section{METHODOLOGY}

Data used in this analysis was collected from 80 non-exporting small and medium sized firms in Malawi. The sample was drawn from two industries namely crafts and agribusiness using simple random sampling method. Business listings obtained from the Malawi Export Promotion Council and the Malawi Confederation of Chambers of Commerce were used to come up with the sampling frame used to draw the sample. A total of 120 firms were targeted for data collection and only 80 usable responses were obtained. This presents an effective response rate of 67 percent. The two industries were targeted due to the fact that most small and medium sized firms involved in exporting in Malawi come from these industries. Quantitative and qualitative criteria was used to define small and medium sized firms for the purposes of this study. This included the fact that the firms needed to have no more than 100 employees and MK 50 million in annual turnover; the firms needed to be privately owned and the owners needed to be actively involved in the running of the business.

A structured questionnaire was the main instrument used to collect the data. The questionnaire was developed after a comprehensive review of literature and conducting interviews with three officials from the Malawi Export Promotion Council. The interviews were aimed at ensuring that issues considered by the export promotion body as of real concern in the development and promotion of exports among small and medium sized firms were adequately addressed in the questionnaire. The questionnaire was then pre-tested on a total of 12 non-exporting firms before coming up with the final version. The pretesting was aimed at ensuring that all the questions were readily understood by the respondents and also to solicit the respondents' views on any issues they felt needed to be covered in the questionnaire. Convenience sampling method was used to select the sample used for pretesting. All observations made and comments received during the pre-testing stage were taken into account when developing the final questionnaire. The questionnaire covered a number of issues relating to exporting. The focus of this paper is on perceived impediments to export involvement.

The owner managers of these firms were personally visited by the researcher and asked to respond to the questionnaire. Personal interviews were also held with the respondents. These were aimed at probing some of the answers given in the questionnaire in order to gain better understanding of the reasoning 
behind them. The collected data was analysed using Statistical Package for Social Science (SPSS) version 18.

\section{RESULTS AND DISCUSSION}

One of the objectives of the study was to investigate levels of interest in exporting among non-exporting firms. In order to do this, the managers were asked to indicate 'yes' or 'no' if their firms had ever discussed or investigated the idea of exporting. They were also asked to indicate the extent to which they agreed with the statement that their firm would consider exporting if they received an export order. This was measured using a five point Likert scale with $1=$ strongly disagree; 2 = disagree; $3=$ neutral; $4=$ agree and $5=$ strongly agree. Table 1 presents the findings of the investigation.

Table 1: Interest in Exporting

\begin{tabular}{|c|c|c|c|c|c|c|}
\hline \multirow{2}{*}{$\begin{array}{l}\text { Investigated/discussed the idea } \\
\text { of exporting }\end{array}$} & \multicolumn{2}{|c|}{ Agribusiness } & \multicolumn{2}{|c|}{ Crafts } & \multicolumn{2}{|c|}{ All firms } \\
\hline & Frequency & $\%$ & Frequency & $\%$ & Frequency & $\%$ \\
\hline Yes & 20 & 58.8 & 26 & 56.5 & 46 & 57.5 \\
\hline No & 14 & 41.2 & 20 & 43.5 & 34 & 42.5 \\
\hline \multicolumn{7}{|c|}{ Firm would consider exporting if it received an order } \\
\hline Strongly disagree/disagree & - & - & 2 & 4.4 & 2 & 2.5 \\
\hline Neutral & 4 & 11.8 & 7 & 15.2 & 11 & 13.8 \\
\hline Strongly agree/agree & 30 & 88.2 & 37 & 80.4 & 67 & 83.7 \\
\hline Mean values & \multicolumn{2}{|c|}{4.50} & \multicolumn{2}{|c|}{4.15} & \multicolumn{2}{|c|}{4.30} \\
\hline
\end{tabular}

According to the results, over half of the firms ( 57.5 percent) had discussed or investigated the possibility of exporting. Similar findings were observed at industry level with 58.8 percent of non-exporting firms from the agribusiness industry and 56.5 percent of those from crafts industry indicating that they had discussed or investigated the idea of exporting. When asked to indicate the extent to which they agreed that their firm would consider exporting if they received an export order, the majority of the firms (83.7 percent) agreed or strongly agreed with the statement. The level of agreement was high amongst firms in both the agribusiness (88.2 percent) and crafts (80.4 percent) industries. None of the firms in the agribusiness industry and only 2 firms in the crafts industry strongly disagreed or disagreed with the fact that their business would consider exporting if they received an order. The mean values were also high (over 4) at both industry and 'all firms' level.

The findings show that there is considerable level of interest in exporting among non-exporting firms as over half of them had discussed or investigated the possibility of exporting. It is however important to bear in mind that despite discussing or investigating the possibility of exporting, these firms had not gone a step further to export their products. During the personal interviews many of the managers indicated that they believed that exporting would be beneficial to their firms' in terms of increased sales volume, higher profits and increased customer base. They however felt that there are many factors that act as impediments to their ability to exploit the benefits associated with export involvement. A typical comment by the managers was:

'Of course, the business would benefit a lot from getting involved in export marketing. However, it is not easy to do so. Export business is more complex than domestic marketing. There are lots of unknowns and if one is not careful, you can end up losing all your money'. 

small and medium sized firms: non-exporters perspective

The fact that over 80 percent of the firms indicated that they would consider exporting if they received an order is also encouraging to those involved in export promotion. The high percentage shows that even the firms that had not discussed or investigated the idea of exporting would not ignore an export opportunity if they received an order.

The second objective of the study was to identify the important perceived impediments to exporting among the firms. In order to do this, respondents were asked to indicate on a five point Likert scale with 1 $=$ strongly disagree; 2 = disagree; $3=$ neutral; $4=$ agree and $5=$ strongly agree, the extent to which they agreed with different factors as important impediments to export involvement. A total of 18 factors were included in the investigation. The factors were subdivided into seven dimensions based on their common theme. The dimensions included financial related impediments, production related impediments, logistical related impediments, human resource related impediments, competition related impediments, information and communication related impediments and those related to foreign country regulations. Overall group means were calculated as a summated average of the factors making up the group. The summated average of all the 18 factors was also calculated in order to find the level of overall perceived impediments. Table 2 presents the results of the analysis at both the individual factor and group level.

According to the results, managers regard 17 of the 18 factors as important impediments to export involvement and were neutral on the remaining factor. These factors had mean values of approximately 3.5 or more. The top six individual impediments in order of importance include insufficient knowledge about export opportunities (mean $=4.00$ ), lack of personnel knowledgeable in exporting (mean value $=$ 3.96), limited information to analyse foreign markets (3.94), product quality not good enough for export (3.93), insufficient production/handling capacity (3.90) and shortage of working capital (3.90). This shows that the most important perceived impediments to export involvement are mainly factors internal to the firm.

Results of the analysis at dimension level show that all managers perceive impediments to export involvement in all the seven areas as all had mean values of approximately 3.5 and more. The most important group of perceived impediments were human resource related (mean value $=3.98$ ). This agrees with observations by Shamsoddoha et al (2009:410) as well as Ruzzier et al (2007:26) who noted that human resource limitations in particular lack of export skills and knowledge of markets are often the most important impediments to export involvement among small and medium sized firms. According to the findings in table 2, human resource related impediments were closely followed by financial related impediments (overall mean $=3.88$ ) and production related impediments (overall mean $=3.87$ ).

Table 2: Impediments to export involvement

\begin{tabular}{|l|l|l|l|l|l|}
\hline Impediments & $\begin{array}{l}\% \\
\text { SD/D }\end{array}$ & $\begin{array}{l}\% \\
\text { Neutral }\end{array}$ & $\begin{array}{l}\text { \% } \\
\text { A/SA }\end{array}$ & $\begin{array}{l}\text { All } \\
\text { firms }\end{array}$ & $\begin{array}{l}\text { Std Dev. } \\
\text { All firms }\end{array}$ \\
\hline Financial related impediments & & & & & \\
- Shortage of working capital & 11.3 & 10.0 & 78.7 & 3.90 & .565 \\
- High cost of finance & 8.8 & 15.0 & 76.2 & 3.86 & .568 \\
\hline Overall - Financial related impediments & & & & 3.88 & .547 \\
\hline Production related impediments & & & & & \\
- Insufficient production/handling capacity & 7.5 & 15.0 & 77.5 & 3.90 & .686 \\
- Difficulties getting enough raw materials/supplies & 6.3 & 22.5 & 71.2 & 3.78 & .693 \\
- Product quality not good enough for export & 5.0 & 18.8 & 76.2 & 3.93 & .742 \\
\hline Overall - production related impediments & & & & 3.87 & .664 \\
\hline Logistical related & & & & & \\
\hline
\end{tabular}




\begin{tabular}{|c|c|c|c|c|c|}
\hline $\begin{array}{l}\text { - Difficulties/slowness in collecting payments } \\
\text { - Excessive documentation required for exporting } \\
\text { - Increase in management complexity }\end{array}$ & $\begin{array}{l}6.3 \\
2.5 \\
5.0\end{array}$ & $\begin{array}{l}48.8 \\
46.3 \\
40.0\end{array}$ & $\begin{array}{l}44.9 \\
51.2 \\
55.5\end{array}$ & $\begin{array}{l}3.46 \\
3.58 \\
3.58 \\
\end{array}$ & $\begin{array}{l}.594 \\
.652 \\
.632 \\
\end{array}$ \\
\hline Overall - logistical related impediments & & & & 3.54 & .599 \\
\hline $\begin{array}{l}\text { Human resource related } \\
\text { - Lack of personnel knowledgeable in exporting } \\
\text { - Insufficient knowledge about export opportunities }\end{array}$ & $\begin{array}{l}6.3 \\
5.0\end{array}$ & $\begin{array}{l}8.8 \\
8.8\end{array}$ & $\begin{array}{l}84.9 \\
86.2\end{array}$ & $\begin{array}{l}3.96 \\
4.00\end{array}$ & $\begin{array}{l}.605 \\
.616\end{array}$ \\
\hline Overall - Human resource related impediments & & & & 3.98 & .587 \\
\hline $\begin{array}{l}\text { Competition related } \\
\text { - Strong international competition } \\
\text { - Inability to offer competitive prices } \\
\text { - High transportation cost }\end{array}$ & $\begin{array}{l}8.8 \\
5.0 \\
5.0\end{array}$ & $\begin{array}{l}17.5 \\
18.8 \\
21.3\end{array}$ & $\begin{array}{l}73.7 \\
76.2 \\
73.7\end{array}$ & $\begin{array}{l}3.85 \\
3.85 \\
3.81\end{array}$ & $\begin{array}{l}.576 \\
.553 \\
.533\end{array}$ \\
\hline Overall - competition related impediments & & & & 3.84 & .551 \\
\hline $\begin{array}{l}\text { Information and communication related } \\
\text { - Existence of language differences } \\
\text { - Difficulties in getting timely communications with } \\
\text { foreign buyers } \\
\text { - Limited information to analyse foreign markets }\end{array}$ & $\begin{array}{l}43.8 \\
6.3 \\
5.0\end{array}$ & $\begin{array}{l}27.5 \\
40.0 \\
37.5\end{array}$ & $\begin{array}{l}28.7 \\
53.7 \\
57.5\end{array}$ & $\begin{array}{l}2.80 \\
3.72 \\
3.94\end{array}$ & $\begin{array}{l}1.107 \\
.886 \\
.998\end{array}$ \\
\hline $\begin{array}{l}\text { Overall - information and communication related } \\
\text { impediments }\end{array}$ & & & & 3.49 & .809 \\
\hline $\begin{array}{l}\text { Foreign country regulations } \\
- \text { Restrictions imposed by government rules and } \\
\text { regulations } \\
\text { - Confusing quality requirements of foreign markets }\end{array}$ & $\begin{array}{l}7.5 \\
5.0\end{array}$ & $\begin{array}{l}52.5 \\
41.3\end{array}$ & $\begin{array}{l}40.0 \\
53.7\end{array}$ & $\begin{array}{l}3.34 \\
3.79\end{array}$ & $\begin{array}{l}.572 \\
.937\end{array}$ \\
\hline $\begin{array}{l}\text { Overall }- \text { foreign country regulations related } \\
\text { impediments }\end{array}$ & & & & 3.56 & .564 \\
\hline Overall perceived impediments to exporting & & & & 3.74 & .381 \\
\hline $\begin{array}{l}\text { Note: } \\
\text { SD = Strongly Disagree } \\
\text { SA = Strongly Agree }\end{array}$ & & & & & \\
\hline
\end{tabular}

Also presented in table 2 are percentages of managers who strongly disagreed or disagreed, those who were neutral, and those who agreed or strongly agreed with each of the 18 items being important impediments to export involvement. According to the results 7 of the 18 items had more than 75 percent of the respondents agreeing or strongly agreeing that they were important impediments to exporting. The items included in order of importance percentage wise insufficient knowledge of export opportunities (86.2\%), lack of personnel knowledgeable in exporting (84.9\%), shortage of working capital $(78.7 \%)$, insufficient production/handling capacity $(77.5 \%)$, production quality not good enough for exporting (76.2\%), high cost of finance (76.2\%), and inability to offer competitive prices (76.2\%). Apart from high cost of finance, all other factors are largely internal to the firm further confirming the importance of internal factors in understanding export involvement.

After analysing the impediments at 'all firms' level, further analysis of the data was conducted in order to examine if there are significant differences in levels of perceived impediments to export involvement between firms in different industries as well as between non-exporters that had discussed or investigated the possibility of exporting before and those that had not. This was done in line with the third objective of the study. The analysis was done at the impediment group level as well as at overall impediment level and not individual item level. The analysis included an examination of the mean values and independent sample $t$ - testing. The independent sample $t$-test was aimed at finding out if the differences in mean 

small and medium sized firms: non-exporters perspective

values between firms in the different groups were statistically significant. Table 3 presents the results of the investigation at industry level while table 4 presents results on the investigation into differences between non-exporters that had discussed or investigated the possibility of exporting before and those that had not.

Table 3: Independent sample t-test - Industry differences

\begin{tabular}{|c|c|c|c|c|c|c|c|}
\hline \multirow{3}{*}{ Impediments - Overall } & \multicolumn{3}{|c|}{ Descriptives } & \multicolumn{4}{|c|}{ T-Test for equality of Means } \\
\hline & \multirow[t]{2}{*}{ Industry } & \multirow[t]{2}{*}{ Mean } & \multirow[t]{2}{*}{$\begin{array}{l}\text { Std. } \\
\text { Deviation }\end{array}$} & \multirow[t]{2}{*}{$\mathrm{T}$} & \multirow[t]{2}{*}{$\begin{array}{l}\text { Sig. (2 } \\
- \\
\text { tailed) }\end{array}$} & \multicolumn{2}{|c|}{$\begin{array}{l}95 \% \text { confidence } \\
\text { interval of the } \\
\text { Mean }\end{array}$} \\
\hline & & & & & & Lower & Upper \\
\hline Financial related & $\begin{array}{l}\text { Agribusiness } \\
\text { Crafts }\end{array}$ & $\begin{array}{l}4.15 \\
3.68\end{array}$ & $\begin{array}{l}.544 \\
.464\end{array}$ & 4.09 & .000 & .237 & .687 \\
\hline Production related & $\begin{array}{l}\text { Agribusiness } \\
\text { Crafts }\end{array}$ & $\begin{array}{l}4.33 \\
3.52\end{array}$ & $\begin{array}{l}.418 \\
.599\end{array}$ & 6.77 & .000 & .573 & 1.050 \\
\hline Logistics related & $\begin{array}{l}\text { Agribusiness } \\
\text { Crafts }\end{array}$ & $\begin{array}{l}3.82 \\
3.33\end{array}$ & $\begin{array}{l}.668 \\
.442 \\
\end{array}$ & 4.01 & .000 & .250 & .745 \\
\hline Human resource related & $\begin{array}{l}\text { Agribusiness } \\
\text { Crafts }\end{array}$ & $\begin{array}{l}4.22 \\
3.80\end{array}$ & $\begin{array}{l}.580 \\
.532\end{array}$ & 3.33 & .001 & .167 & .665 \\
\hline Competition related & $\begin{array}{l}\text { Agribusiness } \\
\text { Crafts }\end{array}$ & $\begin{array}{l}4.09 \\
3.66\end{array}$ & $\begin{array}{l}.558 \\
.471\end{array}$ & 3.78 & .000 & .206 & .666 \\
\hline $\begin{array}{ll}\text { Information } & \text { and } \\
\text { communication related }\end{array}$ & $\begin{array}{l}\text { Agribusiness } \\
\text { Crafts }\end{array}$ & $\begin{array}{l}3.83 \\
3.23\end{array}$ & $\begin{array}{l}.593 \\
.857\end{array}$ & 3.51 & .001 & .261 & .942 \\
\hline $\begin{array}{ll}\text { Foreign } & \text { regulations } \\
\text { related } & \end{array}$ & $\begin{array}{l}\text { Agribusiness } \\
\text { Crafts }\end{array}$ & $\begin{array}{l}3.96 \\
3.27\end{array}$ & $\begin{array}{l}.396 \\
.491\end{array}$ & 6.67 & .000 & .480 & .888 \\
\hline Overall impediments & $\begin{array}{l}\text { Agribusiness } \\
\text { Crafts }\end{array}$ & $\begin{array}{l}4.06 \\
3.48\end{array}$ & $\begin{array}{l}.286 \\
.245\end{array}$ & 9.39 & .000 & .440 & .677 \\
\hline
\end{tabular}

The results according to table 3 show that firms in the agribusiness industry perceive important impediments to their export involvement in all the seven areas investigated. The mean values were all approximately 3.5 or more. Firms from the crafts industry on the other hand perceived important impediments in four of the seven areas. These included in order of importance human resource related impediments (3.80), financial related impediments (3.68), competition related impediments (3.66) and production related impediments (3.52). The managers were neutral on the remaining three factors namely logistical related impediments, information and communication related impediments and foreign country regulations. Results of probing during the in-depth interviews showed that many of the firms in the crafts industry especially those who had not investigated or discussed the possibility of exporting before were not conversant with the logistical requirements associated with exporting as well as foreign regulations that may affect them. This resulted in many of them not being decided in terms of agreeing or disagreeing with the items being important impediments to their firm involvement in exporting. A typical comment received with regards to foreign regulations was:

'It all depends on what the regulations are and whether one is able to meet them or not'.

This shows that having lower mean values especially among non-exporting firms does not necessity mean that firms regard some impediments as of less importance than those with high mean values. An examination of the answers at each point of the scale can help unmask high levels of neutral responses which may indicate lack of knowledge on the part of the respondents. It is also important to note that high 
levels of divergent views can also result in neutral mean values as the extreme views will tend to cancel each other.

Results according to table 3 show that production related barriers were considered by firms in the agribusiness industry as the most important barrier to export involvement (4.33) followed by human resource related impediments (4.22). Typical sentiments observed during the personal interviews were:

'Export orders in this industry are usually in thousands of tonnes. Only firms with large financial muscle and handling capacity can deal with such orders. Additionally agricultural products are often subjected to a lot of scrutiny quality wise and it is not easy to meet these as we lack grading machines.

The results of the independent sample t-test showed that the differences in mean values between firms in agribusiness and crafts industry in all the seven areas as well as in overall level of perceived impediments were statistically significant $(p<0.05)$. The findings agree with observations made by Neupert et al., (2006:537) that firms from different industries may perceive possible barriers to export involvement differently.

Table 4: Independent Sample t-test - Those who investigated/discussed the idea of exporting (group 1) and those who did not (group 2)

\begin{tabular}{|c|c|c|c|c|c|c|c|}
\hline \multirow{3}{*}{ Impediments - Overall } & \multicolumn{3}{|c|}{ Descriptives } & \multicolumn{4}{|c|}{ T-Test for equality of Means } \\
\hline & \multirow[t]{2}{*}{ Groups } & \multirow[t]{2}{*}{ Means } & \multirow[t]{2}{*}{$\begin{array}{l}\text { Std } \\
\text { Deviation }\end{array}$} & \multirow[t]{2}{*}{$\mathrm{T}$} & \multirow[t]{2}{*}{$\begin{array}{l}\text { Sig. }(2- \\
\text { tailed })\end{array}$} & \multicolumn{2}{|c|}{$\begin{array}{l}95 \% \text { confidence } \\
\text { interval of the } \\
\text { Mean }\end{array}$} \\
\hline & & & & & & Lower & Upper \\
\hline Financial related & $\begin{array}{l}\text { Group } 1 \\
\text { Group } 2\end{array}$ & $\begin{array}{l}3.87 \\
3.90\end{array}$ & $\begin{array}{l}.510 \\
.600\end{array}$ & -.221 & .826 & -.275 & .220 \\
\hline Production related & $\begin{array}{l}\text { Group } 1 \\
\text { Group } 2\end{array}$ & $\begin{array}{l}3.91 \\
3.81\end{array}$ & $\begin{array}{l}.643 \\
.697\end{array}$ & .611 & .543 & -.208 & .392 \\
\hline Logistics related & $\begin{array}{l}\text { Group } 1 \\
\text { Group } 2\end{array}$ & $\begin{array}{l}3.55 \\
3.51\end{array}$ & $\begin{array}{l}.597 \\
.610\end{array}$ & .228 & .820 & -.240 & .302 \\
\hline Human resource related & $\begin{array}{l}\text { Group } 1 \\
\text { Group } 2\end{array}$ & $\begin{array}{l}4.03 \\
3.91\end{array}$ & $\begin{array}{l}.627 \\
.529\end{array}$ & .909 & .366 & -.144 & .385 \\
\hline Competition related & $\begin{array}{l}\text { Group } 1 \\
\text { Group } 2\end{array}$ & $\begin{array}{l}3.81 \\
3.87\end{array}$ & $\begin{array}{l}.547 \\
.563\end{array}$ & -.487 & .628 & -.310 & .188 \\
\hline $\begin{array}{l}\text { Information and } \\
\text { communication related }\end{array}$ & $\begin{array}{l}\text { Group } 1 \\
\text { Group } 2\end{array}$ & $\begin{array}{l}3.52 \\
3.44\end{array}$ & $\begin{array}{l}.742 \\
.902\end{array}$ & .438 & .663 & -.286 & .447 \\
\hline $\begin{array}{ll}\text { Foreign } & \text { regulations } \\
\text { related } & \end{array}$ & $\begin{array}{l}\text { Group } 1 \\
\text { Group } 2\end{array}$ & $\begin{array}{l}3.58 \\
3.54\end{array}$ & $\begin{array}{l}.587 \\
.542\end{array}$ & .249 & .804 & -.224 & .288 \\
\hline Overall impediments & $\begin{array}{l}\text { Group } 1 \\
\text { Group } 2\end{array}$ & $\begin{array}{l}3.75 \\
3.71\end{array}$ & $\begin{array}{l}.388 \\
.377\end{array}$ & .442 & .660 & -.134 & .211 \\
\hline
\end{tabular}

The results according to table 4 show that both groups of firms regard human resources related impediments as the most important impediment to their export involvement. This was followed by production related impediments for firms in group 1 and financial related impediments for firms in group 2. 

small and medium sized firms: non-exporters perspective

The results of the independent sample t-test showed that the differences in mean values in all the seven areas as well as in overall impediments were however not statistically significant $(p<0.05)$.

\section{CONCLUSION AND IMPLICATIONS}

The main objective of this paper was to investigate perceived impediments to export involvement among small and medium sized non-exporting firms in Malawi. Before investigating this, it was deemed necessary to investigate levels of interest in exporting among the firms. The results showed that there is a significant amount of interest in export business among the firms. This is based on the fact that the majority of the firms (83.7\%) indicated that they would consider filling an export order if received. Only 2.5 $\%$ of the firms disagreed or strongly disagreed with the fact that they would fill an export order if received. It is however also important to note that although there was high level of interest among the firms as far as not letting export opportunities that come their way to pass by, the results further showed that just over half of the respondents $(57.5 \%)$ had discussed or investigated the possibility of exporting their products before.

Investigations into perceived impediments to export involvement showed that managers of non-exporting firms perceive many factors as important impediments to export involvement. Topping the list were human resource related impediments followed by financial related impediments and production related impediments. On human resource related impediments, managers felt that they lacked personnel knowledgeable in exporting and had insufficient knowledge about export opportunities. On financial related impediments, firms regarded both shortage of working capital and high cost of finance as important impediments to export involvement. On production related impediments, major concerns were to do with product quality not being good enough for export markets, insufficient production/handling capacity and difficulties in getting enough raw materials/supplies. Investigations on perceived impediments to export involvement at industry level showed that there are significant differences in the way firms in the two industries regarded different impediments to export involvement. In general, firms in agribusiness perceived more impediments to export involvement than those in crafts. This is more likely due to factors inherent in the nature of the industries. Firms in agribusiness for example, deal with products that are mostly bulky and largely undifferentiated. Their export orders are usually in large masses (tonnes). Firms in crafts industry on the other hand need not deal in large masses in order to export. Additionally, their products are easier to differentiate.

The findings of this study have wider practical implications on export promotion initiatives among nonexporting small and medium sized firms. The fact that a significant number of non-exporting firms have interest in export markets is something export promotion bodies can capitalise on as it shows the existence of untapped export potential. What is important in dealing with such firms is to identify and help them manage the factors that are preventing them from taking advantage of the potential benefits of export involvement. Of critical importance according to the findings of this study is to help firms acquire skills and capabilities that can enable them take advantage of export markets. Export assistance programs such as workshops and seminars can be helpful in this regard. Apart from imparting theoretical knowledge, export promotion agencies should seriously consider helping managers of non-exporting firms acquire export related skills and capabilities through experiential learning. This can be done by promoting networking between non-exporters and existing exporters.

The findings of this study have also practical implications on the part of individual managers of nonexporting firms interested in export markets. Firstly it is important for managers to realise the need on their part to take active steps towards acquiring export skills and capabilities. While external environmental conditions can be significant impediments to export involvement, it is mainly factors 
internal to the firm especially resource commitments made and capabilities developed that can help explain why within an industry and country some firms successful export while others do not. Managers interested in export markets need to ensure that they take advantage of the available export promotion services in the country by participating in scheduled workshops and other programs designed to promote exports. They also need to realise the need to devote significant amount of resources to information gathering and generation of sales. One of the best approaches that can be taken to generate export orders is through attending foreign trade shows.

\section{REFERENCES}

Ahmed, Z. Julian, C. Baalbaki, I. and Hadidian, T. 2006. Firm internationalisation and export incentives from a Middle Eastern perspective. Journal of Small Business and Enterprise Development, 13(4) 660-669.

Altintas M, Tokol T, Harcar T. 2007. The effects of export barriers on perceived export performance: An empirical research on SME's in Turkey. EuroMed Journal of Business 2(1): 36-56.

Hook, R. and Czinkota, M. (1988). Export activities and prospects of Hawaiian firms. International Marketing Review, 5(4): 51-57

Hutchinson, K. Fleck, E. Lloyd-Reason, L. 2009. An investigation into the initial barriers to internationalisation: Evidence from small UK retailers. Journal of Small Business and Enterprise Development 16(4): 544-568.

Kalafsky, R. 2009. Export challenges and potential strategies: Canadian manufacturers in the Chinese market. Journal of Small Business and Enterprise Development, 16(1): 47-59.

Khorana S. Verousis T. Perdikis N. 2010. Perceptions of export problems in EU-India Trade: Evidence from small and medium firms. [Online] Available:

http://www.etsg.org/ETSG2010/papers/Khorana.pdf [Accessed $20^{\text {th }}$ October 2010].

International Monetary Fund. 1986. Directions of trade statistics yearbook, 1986. International Monetary Fund, Statistics Department, Washington DC

Lages, L. and Montgomery, D. 2005. The relationship between export assistance and performance improvement in Portuguese export ventures. European Journal of Marketing, 39(7/8): 755-784.

Lee, K. and Carter, S. 2009. Global marketing management: Changes, new challenges, and strategies. New York: Oxford University Press

Leonidou, L. 2004. An analysis of the barriers hindering small business export development. Journal of Small Business Management, 42 (3): 279-302.

Leonidou, L.C. and Katsikeas, C.S. 1996. The export development process: An integrative review of empirical models. Journal of International Business Studies, 27(3): 517-51.

Leonidou, L. Katsikeas, C. Palihawadana, D. and Spyropoulou, S. 2007. An analytical review of the factors stimulating smaller firms to export: Implications for policy-makers. International Marketing Review, 24(6): 735-770. 
Malawi Government. 2007. Revised Malawi micro, small and medium enterprise policy. Ministry of Industry Trade and Private sector Development, Malawi.

Miankhel, A. Thangavelu, S. and Kalirajan, K. (2009). Foreign direct investment, exports, and economic growth in selected emerging countries: Multivariate VAR analysis. MPRA Paper No. 22763, [Online] Available: http://mpra.ub.uni-muenchen.de/22763/1/MPRA paper 22763.pdf [Accessed $5^{\text {th }}$ November 2010].

Morgan, E. 1999. Environmental determinants of export decision-making: Conceptual issues regarding the domestic market. European Business Review 99(5): 323-331.

Neupert, K. Baughn, C. and Dao, T. 2006. SME exporting challenges in transitional developed economies. Journal of Small Business and Enterprise Development, 13(4): 535-545.

Organisation for Economic Cooperation and Development. 2000. Small and medium-sized enterprises: Local strength, global reach. OECD Policy Brief, June 2000. OECD, Paris.

Organisation for Economic Cooperation and Development. 2008. Removing barriers to SME access to international markets. OECD, Paris

Pinho, J and Martins, L. 2010. Exporting barriers: Insights from Portuguese small and medium sized exporters and non-exporters. Journal of International Entrepreneurship, 8(3): 254-272.

Ruzzier, M. Antoncic, B. Hisrich, R. and Konecnic, M. 2007. Human capital and SME internationalisation: a structural equation modelling study. Canadian Journal of Administrative Sciences, 24(1): 15-29.

Shamsuddoha, A. Ali, M. and Ndubisi, N. 2009. Impact of government export assistance on internationalisation of SMEs from developing nations. Journal of Enterprise Information Management, 22(4): 408-422.

Singh, G. Pathak, R. and Naz, R. 2010. Issues faced by SMEs in the internationalisation process: results from Fiji and Samoa. International Journal of Emerging Markets, 5(2): 153-182.

Su, L. and Adams, J. 2010. Export capacity impact factors on Chinese SMEs: A survey analysis of Fujian Province. Journal of Chinese Economic and Foreign Trade Studies, 3(1): 54-70.

The Donor Committee for Enterprise Development. 2008. Supporting business environment reforms, practical guidance for development agencies. World Bank Publications: Washington D.C..

World Trade Organisation. 2010. International Trade Statistics 2010. WTO, Geneva, Switzerland. [Online] Available: http://www.wto.org/english/res e/statis e/its2010 e/its2010 e.pdf [Accessed 10th January 2011].

Yannopoulos, P. 2010. Factors motivating exports: The Canadian Evidence. The Journal of International Management Studies 5(2): 82-88. 